\title{
Caveolin 1 and G-Protein-Coupled Receptor Kinase-2 Coregulate Endothelial Nitric Oxide Synthase Activity in Sinusoidal Endothelial Cells
}

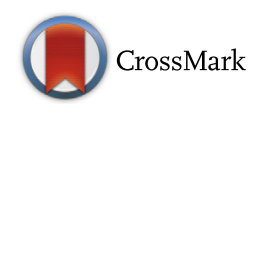

\author{
Songling Liu, ${ }^{*}$ Richard T. Premont, ${ }^{\dagger}$ Shweta Singh, ${ }^{*}$ and Don C. Rockey*
}

From the Department of Medicine, ${ }^{*}$ Medical University of South Carolina, Charleston, South Carolina; and the Department of Medicine, ${ }^{\dagger}$ Duke University Medical Center, Durham, North Carolina

Accepted for publication

November 28, 2016.

Address correspondence to Don

C. Rockey, M.D., Department of Medicine, Medical University of South Carolina, 96 Jonathan Lucas St, Ste 803, MSC 623, Charleston, SC 29425. E-mail: rockey@ musc.edu.

\begin{abstract}
Liver injury leads to a vasculopathy in which post-translational modifications of endothelial nitric oxide synthase (eNOS) lead to impaired nitric oxide synthesis. We hypothesized that caveolin 1 (CAV1), a well-known eNOS interactor, regulates eNOS activity in sinusoidal endothelial cells (SECS) via its interaction with G-protein-coupled receptor kinase-2 (GRK2) that also post-translationally modifies eNOS. Liver injury with portal hypertension was established using bile duct ligation in rats. CAV1 function was modified using a CAV1 scaffolding domain construct and cDNAs encoding wild-type CAV1, and CAV1 phosphorylation was increased in injured SECs, resulting in increased GRK2-CAV1 interaction and decreased eNOS activity. In injured SECs, endothelin-1 blocked CAV1 phosphorylation induced by CAV1 scaffolding domain, indicating that CAV1 interaction with GRK2 is inversely regulated by endothelin-1 and CAV1 scaffolding domain after liver injury. In addition, after transduction with DNA encoding wild-type CAV1 into SECs isolated from Cav1-deficient mice, GRK2 association with CAV1 was evident, whereas transduction with a dominant negative CAV1 mutated at tyrosine 14 reduced the interaction. Finally, isoproterenol-induced GRK2 phosphorylation enhanced CAV1-GRK2 interaction and reduced eNOS activity. Our data suggest a novel mechanism and model in which CAV1 phosphorylation facilitates CAV1 scaffolding and GRK2-CAV1 interaction, thus clustering eNOS within a complex that inhibits eNOS activity. This process takes place in injured, but not in normal, SECs. (Am J Pathol 2017, 187: 896-907; http://dx.doi.org/10.1016/j.ajpath.2016.11.017)
\end{abstract}

Endothelial nitric oxide synthase (eNOS) is well known to be the major source of nitric oxide (NO) in the vasculature, ${ }^{1}$ and aberrant regulation of eNOS activity has been linked to a range of vascular diseases. ${ }^{2,3}$ In the liver, we and other investigators have shown that after liver injury, eNOS function is reduced, generating an endothelialopathy in the hepatic sinusoid. ${ }^{4,5}$ This endothelial dysfunction appears to be linked to a complex series of post-translational molecular events; one prominent event is mediated by G-protein-coupled receptor (GPCR) kinase-2 (GRK2), which is known to dampen GPCR signaling. GRK2 has been shown to bind directly to caveolin-1 (CAV1). ${ }^{6,7}$ In addition, we have demonstrated that GRK2 expression is increased in sinusoidal endothelial cells (SECs) after liver injury, resulting in reduced eNOS-specific activity, reduced NO production, and elevated portal pressure. ${ }^{8}$ Although
GRK2 is known primarily as a regulator of GPCR function, we and others have suggested that GRK2 also has multiple non-GPCR functions, ${ }^{9}$ presumably via its phosphorylation of non-GPCR substrates.

CAV1, ${ }^{10}$ a structural coat component of caveolae known to be important in protein-protein interactions ${ }^{11-15}$ in the cell, has been shown to play a role in the regulation of numerous signaling pathways, both in physiological and pathophysiological settings, ${ }^{16-20}$ including eNOS-signaling cascade. $^{21}$ In endothelial cells, eNOS appears to be associated with CAV1, ${ }^{22}$ specifically leading to reduced eNOS phosphorylation at serine 1177 and resulting in reduced NO generation. ${ }^{20,23-25}$ Although the association of CAV1 and

Supported by NIH grant R01 DK57830 (D.C.R.).

Disclosures: None declared. 
eNOS is well established, available data suggest that other proteins may also be involved. For example, CAV1 binds to other proteins, such as GRK2, affecting its activity. ${ }^{6}$ In addition, CAV1 is phosphorylated on tyrosine-14 by Src and Fyn, ${ }^{26}$ and this phosphorylation appears to be important functionally. ${ }^{27,28}$ How caveolin affects the enzyme activity of its partners in different systems remains largely unexplored.

Given the known link between eNOS and GRK2 in injured SECs, the reported regulation of eNOS by CAV1, and the putative importance of CAV1 phosphorylation on other protein functions, we hypothesized that CAV1 and GRK2 may cooperate to regulate eNOS function. Furthermore, we postulated that CAV1 phosphorylation was likely to be important in signaling to eNOS. Thus, we examined the association of CAV1 with eNOS and GRK2 in normal and injured SECs and the effect of the CAV1 scaffolding domain on eNOS activity. We also modulated GPCR signaling with isoproterenol (Iso; known to increase GRK2 phosphorylation and dampen GPCR signaling) ${ }^{29,30}$ and the $\mathrm{ET}_{\mathrm{B}}$ receptor (to enhance GPCR signaling) to understand how CAV1 interaction with GRK2 regulates eNOS/NO signaling. Our data indicate that the CAV1-GRK2 interaction is important for regulation of eNOS function and suggest new mechanisms of eNOS post-translational regulation via protein-protein interactions in injured SECs.

\section{Materials and Methods}

\section{Reagents}

Endothelin-1 (ET-1) was purchased from American Peptide Company (Sunnyvale, CA). A synthetic peptide corresponding to the CAV1 scaffolding domain (CSD; DGIWKASFTTFTVTKYWFYR) and a scrambled peptide (WGIDKAFFTTSTVTYKWFRY) were purchased from Sigma-Aldrich (St. Louis, MO). The tyrosine phosphorylation inhibitor, 4-amino-5-(4-chlorophenyl)-7-(dimethylethyl) pyrazolo[3,4-d]pyrimidine (PP2), and a $\beta$-adrenergic agonist, Iso, were also purchased from Sigma-Aldrich.

\section{Animals}

All animal studies were conducted using male mice and rats, according to federal guidelines, and approved by the Institutional Animal Care and Use Committee at Medical University of South Carolina (Charleston, SC).

\section{Animal Model of Liver Injury with Portal Hypertension}

Liver injury and portal hypertension were induced by performing bile duct ligation in 400-g male Sprague-Dawley rats, as described. ${ }^{31}$ Briefly, bile duct ligation was performed by surgical isolation and ligation of the common bile duct. This model generates a portal-based fibrogenic response and portal hypertension 10 to 14 days after surgery. ${ }^{31,32}$ In sham-operated rats, laparotomy without isolation and section of the bile duct was performed. All animals received humane care according to NIH guidelines; studies were approved by the Medical University of South Carolina Institutional Animal Care and Use Committee.

\section{Cell Isolation and Culture}

SECs were isolated from male Sprague-Dawley rats (450 to $500 \mathrm{~g}$ ) (Harlan, Indianapolis, IN) or male Cavl wild-type $\left(C A V 1^{+/+} ; C 57 \mathrm{Bl} / 6 J\right)$ and knockout mice $\left(C A V 1^{-1-}\right.$ with C57 Bl/6J background) mice ${ }^{33}$ from Jackson Laboratory (Bar Harbor, ME). In brief, after in situ perfusion of the liver with $20 \mathrm{mg} / \mathrm{dL}$ pronase (Roche Molecular Biochemicals, Indianapolis, IN), followed by collagenase (Worthington Biochemical Corp., Lakewood, NJ), dispersed cell suspensions were removed from a layered discontinuous density gradient of $8.2 \%$ and $15.6 \%$ Accudenz (Accurate Chemical and Scientific, Westbury, NY), and further purified by centrifugal elutriation (18 mL/minute flow). Cells were grown in medium containing $20 \%$ serum $(10 \%$ horse plus $10 \%$ fetal calf). The purity of endothelial cells was documented by their uptake of fluorescently labeled di-I-acetoacetylated low-density lipoprotein. We have additionally performed immunohistochemical experiments with antibodies specific for Kupffer cells and hepatic stellate cells, as described. ${ }^{34,35}$ Cell isolations contain rare Kupffer cells and small numbers of stellate cells. We routinely use only isolates of $>95 \%$ purity. $^{36}$

\section{Adenovirus}

Adenovirus containing full-length endothelin-B receptor was a gift from Michael B. Fallon (The University of Texas Health Science Center at Houston, Houston, TX). ${ }^{37}$ Adenovirus containing an empty vector and adenovirus containing full-length endothelin-B receptor were purified from infected 293 cells, as described. ${ }^{32}$ We confirmed the efficiency of adenovirus infection of SECs, as described previously. ${ }^{38}$ SECs were exposed to adenovirus in $2 \%$ serum for 16 hours, and medium was exchanged; cells were then harvested at the specified time points.

\section{Plasmids}

Human Myc-tagged CAV1 wild-type and tyrosine 14 mutated to phenylalanine (CAV1 Y14F) was obtained from Dr. Ivan R. Nabi (University of British Columbia, Vancouver, BC, Canada) ${ }^{39}$ For transient transfection, plasmid DNA encoding CAV1 (or an empty vector as control) was transfected into SECs isolated from $C A V 1^{-/-}$mice $\left(C A V I^{+/+}\right.$ mice as additional control) using FuGENE 6 transfection reagent from Promega Corp. (Madison, WI), according to the manufacturer's instructions. Transfected proteins and cell culture conditioned medium were routinely analyzed at 36 hours after transfection. Transfection 
efficiency was confirmed using anti-c-myc antibody from Abcam (Cambridge, MA).

\section{Isolation of Cell Fractions}

Cells isolated from normal and injured (bile duct ligation) primary SECs were harvested after being cultured for 16 to 24 hours. Cell compartment proteins were then separated into cytosolic, membrane, and nuclear fractions using the Fraction-PREP Cell Fractionation System (BioVision, Mountain View, CA), according to the manufacturer's protocol. Immunoblotting was performed on the fractions.

\section{Immunoprecipitation, Immunoblotting, and Immunofluorescence Microscopy}

Immunoprecipitation assays were used to investigate the interaction of caveolin 1 with GRK2 or $\mathrm{ET}_{\mathrm{B}} \mathrm{R}$, and detection of GRK2 activity or tyrosine phosphorylation in primary SECs. Briefly, cell lysates (200 $\mu \mathrm{g}$ total protein) were subjected to immunoprecipitation with antibody to GRK2 (Santa Cruz Biotechnology, Dallas, TX) or antibody to CAV1 (BD Transduction Laboratories, San Jose, CA) overnight. Immunoprecipitation using a control nonimmune IgG was used in each experiment. Immunocomplexes were captured by incubating with protein A beads (GE Healthcare Bio-Sciences, Pittsburgh, PA) for 4 hours at $4^{\circ} \mathrm{C}$. Immunoprecipitated proteins were separated by SDSPAGE.

Immunoblotting was performed, as described, ${ }^{36}$ using specified primary antibodies, including anti-CAV1 antibody (1:1000; BD Transduction Laboratories), anti-phosphoCAV1-Y14 (1:1000; Santa Cruz Biotechnology), anti-eNOS (1:1000; BD Transduction Laboratories), anti-phosphoeNOS-Ser1177 (1:1000; BD Transduction Laboratories), anti-GRK2 antibody (1:1000; BD Transduction Laboratories or Cell Signaling Technology, Danvers, MA), anti-ET ${ }_{B} R$ antibody (1:1000; Molecular Probes, Carlsbad, CA), antiphosphotyrosine 4G-10 antibody (1:1000; Merk Millipore Crop, Billerica, MA), and horseradish peroxidaseconjugated secondary antibody. Specific signals were visualized using West Pico enhanced chemiluminescence reagents (Rockford, IL), as per the manufacturer's instructions, and were scanned and quantitated with Syngene G Box Chemi XT4 (Division of Synoptics Group, Frederick, MD) and Genetools gel analysis software version 4.03.00 (Division of Synoptics Group). Immunoblot images shown are representative of other replicate experiments.

Immunofluorescence microscopy was used to investigate the colocalization of CAV1 with GRK2. Briefly, primary SECs from normal or injured livers were fixed in $4 \%$ paraformaldehyde/phosphate-buffered saline and permeabilized in $0.2 \%$ Trition $\mathrm{X}-100$, and then labeled with monoclonal anti-CAV1 antibody (1:200; BD Transduction Laboratories), followed by Alexa Fluor 488 donkey antimouse IgG secondary antibody (Molecular Probes) and with polyclonal anti-GRK2 antibody (1:200; Santa Cruz Biotechnology), followed by Alexa Fluor 555 donkey anti-rabbit IgG secondary antibody (Molecular Probes). Fluorescent labeling was visualized using a Zeiss LSM-510 confocal microscope (Carl Zeiss Inc., Thornwood, New York), and images were overlaid with Zeiss LSM Image Browser version 4.2.0.121 (Carl Zeiss Inc.).

\section{NO Measurement}

To assess NO production, we analyzed the release of nitrite, the stable breakdown product of NO, using a nitric oxide assay kit (Abcam, Cambridge, MA), as per the manufacturer's instructions. Briefly, a standard curve was generated to measure levels between 1 and $100 \mu \mathrm{mol} / \mathrm{L}$ of nitrite per well. Cells were harvested, and an aliquot of cell

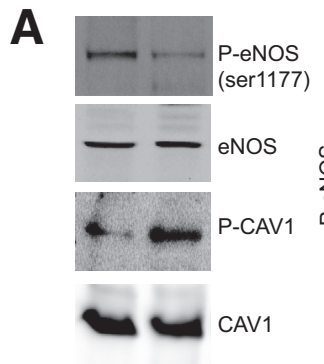

NEC BEC

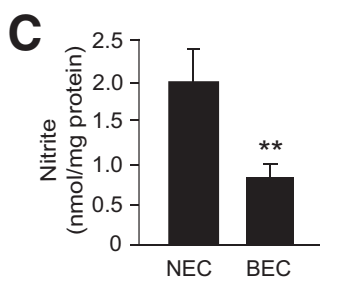

B

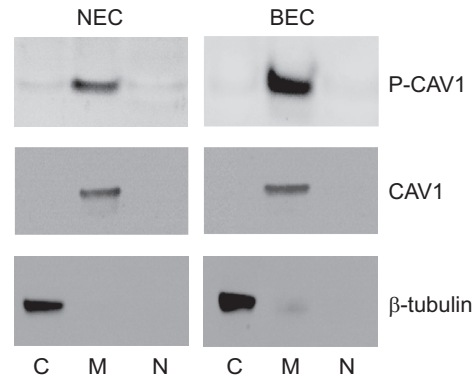

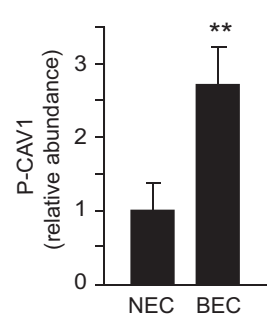

Figure 1 Expression of caveolin 1 (CAV1) phosphorylation in normal and injured sinusoidal endothelial cells (SECs). SECs were isolated from normal with sham-operation (NEC) and injured [by bile duct ligation (BDL); $B E C$ ] rat livers, as described in Materials and Methods. A: Total SEC protein $(50 \mu \mathrm{g})$ was subjected to immunoblotting to detect endothelial nitric oxide synthase (eNOS) phosphorylation at Ser 1177 (P-eNOS), total eNOS, caveolin 1 phosphorylation at Y14 (P-CAV1), and total caveolin 1 (CAV1) separately. Specific bands corresponding to P-eNOS or P-CAV1 were quantitated and presented graphically as the ratio of P-eNOS/total eNOS or P-CAV1/total CAV1 separately. B: Total protein cell compartment proteins were fractionated, as in Materials and Methods, and subjected to immunoblotting as in A. Specific bands corresponding to P-CAV1 were quantitated and presented graphically. C: Conditioned media from the same cells as in A were collected and nitrite levels were measured as in Materials and Methods; quantitative data are shown graphically. Data are presented as means \pm SEM. $n=3$ for each group $(\mathbf{A}-\mathbf{C}) .{ }^{* * P}<0.01$ versus NEC. C, cytosolic; M, membrane; $\mathrm{N}$, nuclear. 
lysate was used to determine total protein concentration (Bio-Rad Laboratories, Hercules, CA). Conditioned medium and standards were exposed to Griess reagent, following the manufacturer's instructions, and developed over 10 minutes. The optical density of each well was detected at $540 \mathrm{~nm}$ after zeroing against a blank well, using a linear model in a Molecular Devices (Sunnyvale, CA) microplate reader.

A
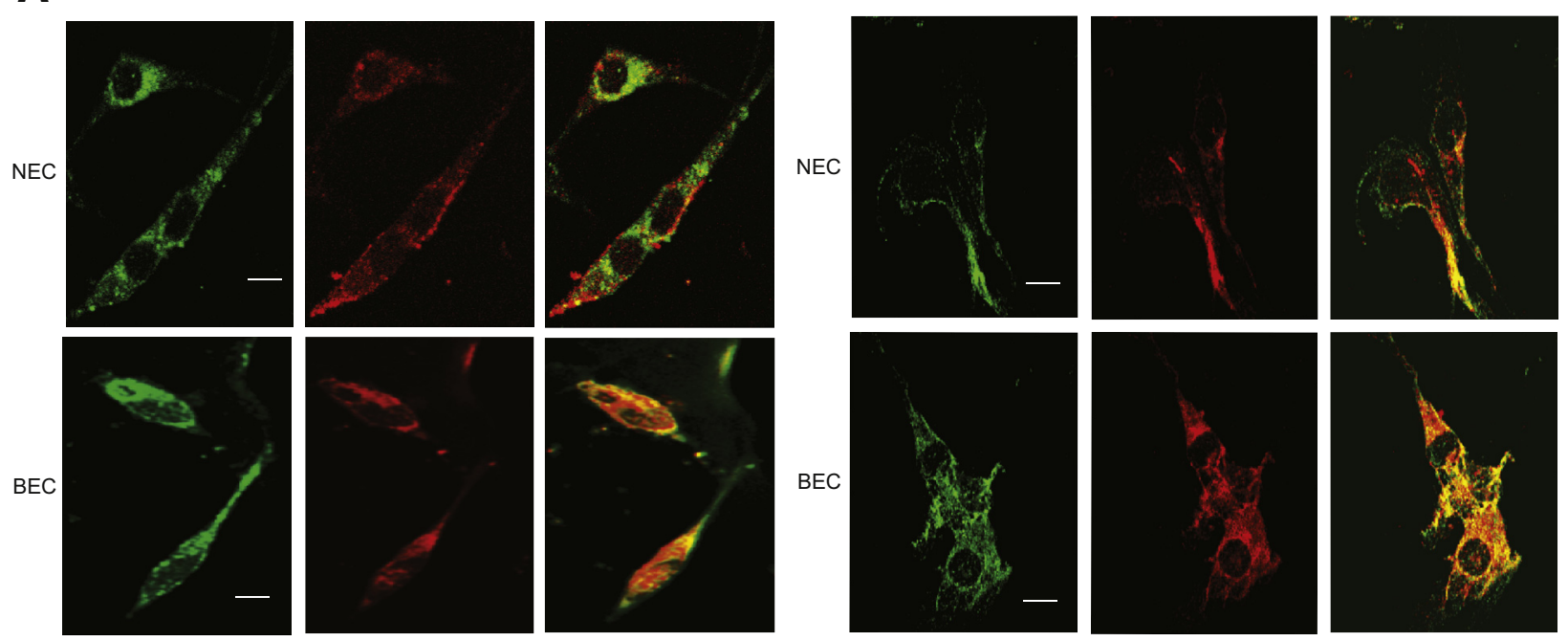

GRK2

CAV1

Merge

GRK2

P-CAV1

Merge

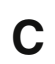

B

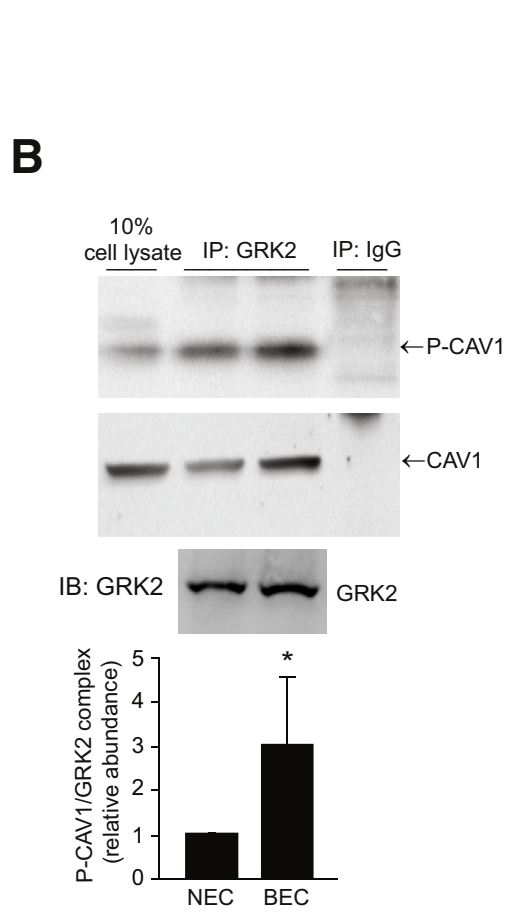

IB:
eNOS

IP: CAV1

IP: CAV1
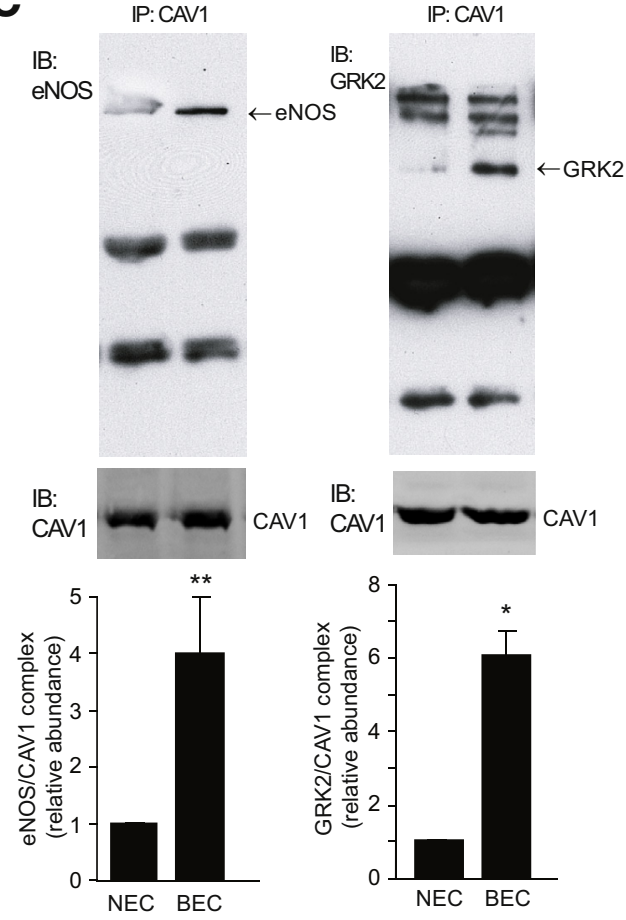

IB:
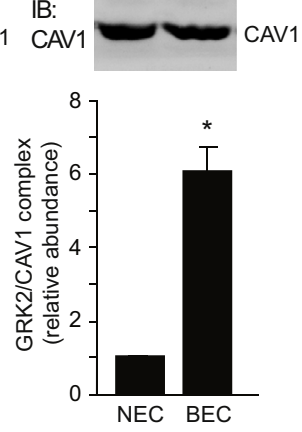

Figure 2 Caveolin 1 (CAV1) and G-protein-coupled receptor kinase-2 (GRK2) interaction is enhanced in injured sinusoidal endothelial cells (SECs). A: Immunohistochemical localization of CAV1 and GRK2 or P-CAV1 and GRK2 in SECs isolated from normal with sham-operation (NEC) and injured [by bile duct ligation (BDL); BEC] rat livers. GRK2 is green; and CAV1 or P-CAV1, red. Representative images from $>10$ images are shown. B: GRK2 from NEC or BEC was immunoprecipitated (IP), and associated P-CAV1 or CAV1 protein was assessed by immunoblotting (IB); GRK2 protein levels used for immunoprecipitation were assessed by immunoblotting with antibody to GRK2. Immunoprecipitation with IgG as a control and the expression of P-CAV1 or CAV1 from $10 \%$ of the total cell lysate used for immunoprecipitation are also shown; a representative of three images is shown. Bands corresponding to P-CAV1 were quantified and normalized to the level of immunoprecipitated GRK2. C: The interaction of CAV1 and endothelial nitric oxide synthase (eNOS) or GRK2 in normal (NEC) and BDL SECS (BEC) was measured by immunoprecipitation with anti-CAV1 antibody and immunoblotting with antibody to eNOS or GRK2. CAV1 levels in the immunoprecipitate were assessed by immunoblotting with CAV1 antibody. Bands corresponding to eNOS or GRK2 were quantified and normalized to the level of immunoprecipitated CAV1. Data are presented as means \pm SEM (B and $\mathbf{C}) . n=3$ for each group (B and $\mathbf{C})$. ${ }^{*} P<0.05,{ }^{*} P<0.01 \mathrm{BEC}$ versus NEC. Scale bars $=10 \mu \mathrm{m}(\mathbf{A})$. 


\section{Statistical Analysis}

All experiments were performed in replicates using cells isolated from different rats. All results were expressed as the means \pm SEM. We performed statistical analysis using the two-tailed $t$-test $P<0.05$ was considered statistically significant.

\section{Results}

\section{CAV1 Phosphorylation in Injured SECs}

We first examined eNOS protein expression, eNOS phosphorylation (at Ser 1177), and NO production in normal and injured SECs. As previously reported, ${ }^{4,5}$ we found that total eNOS expression did not change after injury, but eNOS phosphorylation and NO production in injured SECs were significantly decreased (Figure 1, A and C).

We also initially examined CAV1 protein expression and CAV1 phosphorylation in normal and injured SECs. We found that CAV1 expression did not change after injury, but that there was a fourfold to fivefold increase in CAV1 phosphorylation at Y14 in injured SECs in both total protein lysate (Figure 1A) and the isolated membrane fraction (Figure 1B). These results suggested a role for CAV1 phosphorylation in SEC dysfunction after injury.

\section{CAV1-GRK2 Interaction in Injured SECs}

CAV1 binding to eNOS leads to reduced eNOS activity. ${ }^{40,41}$ Similarly, GRK2 interaction with eNOS also leads to reduced eNOS activity. ${ }^{42}$ GRK2 contains CAV1-binding motifs that mediate its binding to CAV1 ${ }^{6,43}$ We hypothesized that GRK2 inhibits eNOS signaling, in part, through interaction with CAV1. Because it is unknown whether the interaction of CAV1 and GRK2 occurs in liver SECs and whether this may be altered after liver injury, we examined whether CAV1 interacts with GRK2 in SECs and whether this complex also contains eNOS, by performing dual-immunolabeling experiments. Immunofluorescence staining showed localization of both CAV1 and GRK2 in the cytoplasm and plasma membrane. Interestingly, colocalization was more prominent in injured cells (Figure 2A). More importantly, phospho-CAV1 and GRK2 colocalization also was significant in injured cells (Figure 2A). Given the apparent colocalization of GRK2 with both CAV1 and phospho-CAV1, we next explored
A
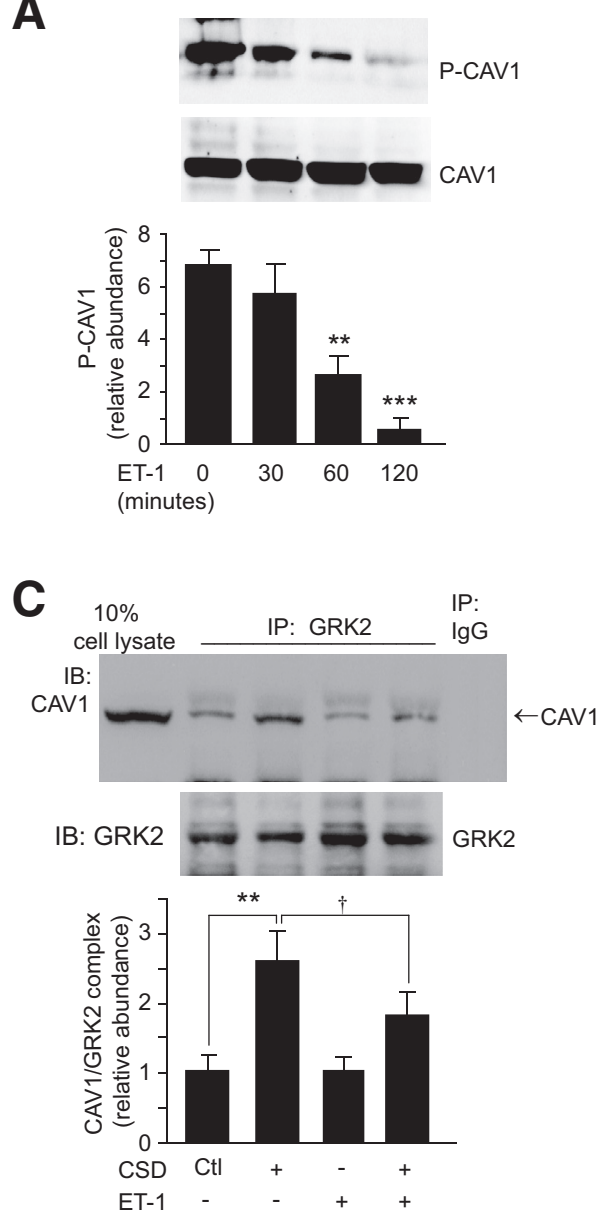

B
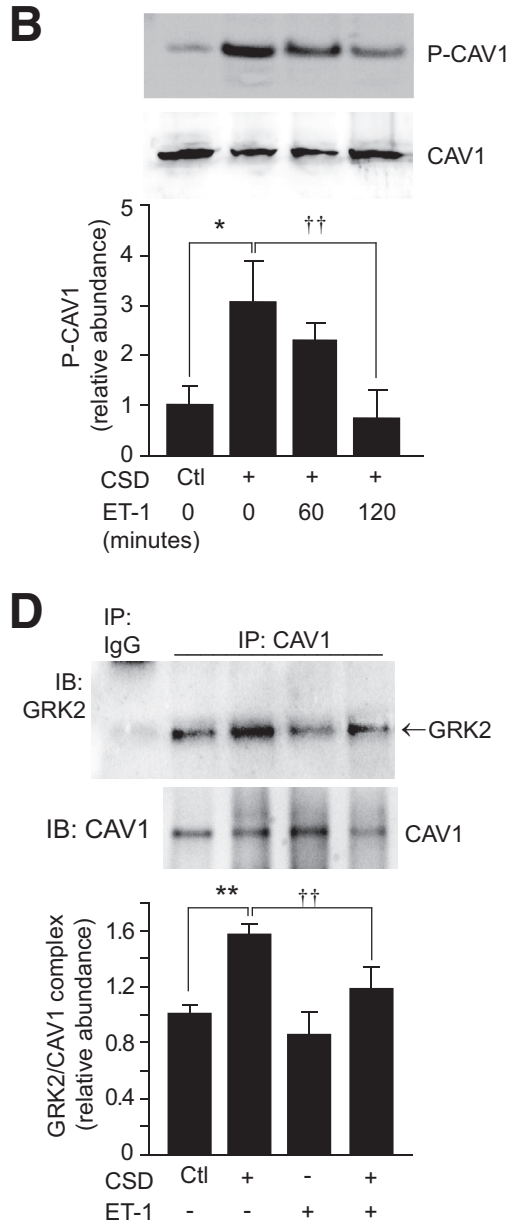

Figure 3 The effects of caveolin 1 (CAV1) scaffolding domain (CSD) on CAV1 phosphorylation and G-protein-coupled receptor kinase-2 (GRK2) -CAV1 interaction. A: Sinusoidal endothelial cells (SECs) from injured [by bile duct ligation (BDL)] rat livers were exposed to $20 \mathrm{nmol} / \mathrm{L}$ endothelin-1 (ET1) from 0 to 120 minutes. Cell lysates were subjected to immunoblotting to detect P-CAV1 or CAV1. Bands corresponding to P-CAV1 and CAV1 were quantified, and the ratio of P-CAV1 at 120 minutes of ET-1 exposure versus total CAV1 at the same conditions was set as 1. B: SECs from injured (BDL) rat livers were pretreated with $5 \mu \mathrm{mol} / \mathrm{L}$ CSD or control scrambled peptide for 6 hours before stimulation with $20 \mu \mathrm{mol} / \mathrm{L}$ ET-1 for the indicated times. Cell lysates were subjected to immunoblotting with anti - phospho-caveolin 1 (Tyr14) and anti-CAV1 antibodies separately. Bands corresponding to P-CAV1 and CAV1 were quantified, and the ratio of P-CAV1 without treatment versus total caveolin 1 under the same conditions was set as 1. C and D: GRK2 or CAV1 from the same treatment as in B was immunoprecipitated (IP) and the presence of associated CAV1 (C) or GRK2 (D) protein was assessed by immunoblotting (IB); GRK2 and CAV1 levels used for immunoprecipitation were assessed by immunoblotting with antibody to GRK2 (C) or CAV1 (D). Specific CAV1 or GRK2 bands were quantified and normalized to the level of immunoprecipitated GRK2; $10 \%$ of total cell lysate used to detect CAV1 position and immunoprecipitation with IgG are also shown as indicated. Data are presented as means \pm SEM. $n=3$ for each group (A-D). ${ }^{*} P<0.05,{ }^{* *} P<0.01$, and ${ }^{* * *} P<0.001$ versus 0 minute $(\mathbf{A})$ or control scrambled peptide treatment (B-D) $;{ }^{\dagger} P<0.05,{ }^{\dagger \dagger} P<0.01$ CSD alone versus CSD plus ET-1. Ctl, control scrambled peptide. 
A

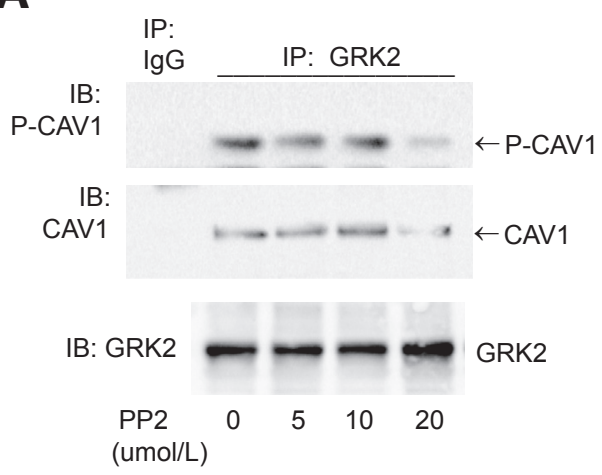

B

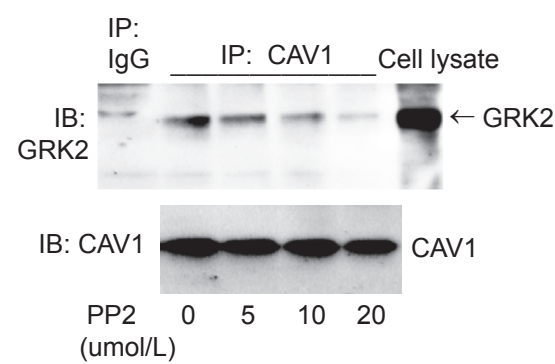

C

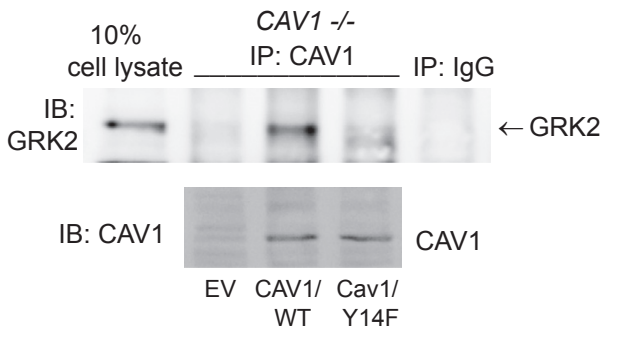

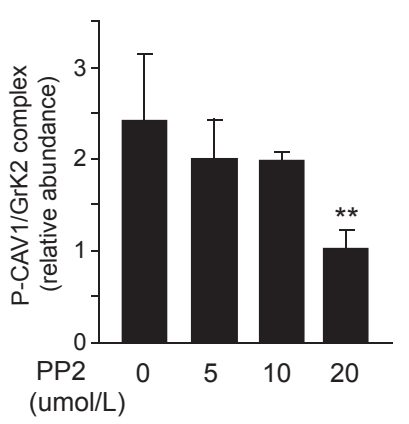

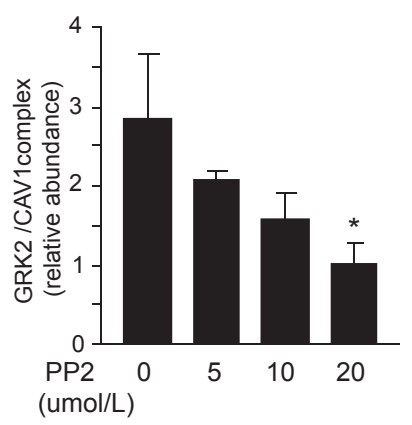

D

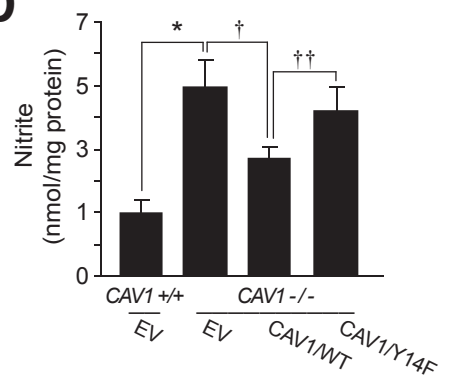

Figure 4 Caveolin 1 (CAV1) phosphorylation dynamically regulates G-protein-coupled receptor kinase-2 (GRK2)-CAV1 interaction. A: Sinusoidal endothelial cells (SECS) isolated from injured [by bile duct ligation; $\mathrm{BEC}]$ rat livers were exposed to the tyrosine inhibitor, PP2 ( 5 to $20 \mu \mathrm{mol} / \mathrm{L}$ for 2 hours), and cells were harvested and cell lysates were subjected to immunoprecipitation (IP) with antibody to GRK2 and the presence of associated PCAV1 or total CAV1 was assessed by immunoblotting (IB) with antibody to P-CAV or CAV1; GRK2 protein levels used for immunoprecipitation were assessed by immunoblotting with antibody to GRK2. Specific bands of P-CAV or CAV1 were quantified and normalized to the level of immunoprecipitated GRK2 and presented in the graph. Immunoprecipitation with IgG is also shown as indicated. B: CAV1 from the same cells as in $\mathbf{A}$ was immunoprecipitated and the presence of associated GRK2 protein was assessed by immunoblotting. CAV1 protein levels used for immunoprecipitation were assessed by immunoblotting with antibody to CAV1 (top panel). Specific GRK2 bands were quantified and normalized to the level of immunoprecipitated CAV1 and presented in the graph in the bottom panel, total cell lysate used to detect GRK2 position and immunoprecipitation with IgG are also shown (top panel). C: SECS isolated from CAV1 knockout mice $\left(\mathrm{Cav}^{-/-}\right)$were transfected with CAV1 fulllength cDNA [CAV1/wild type (WT)], CAV1-Y14F mutation which has inactivated CAV1 tyrosine phosphorylation site at 14 (CAV1/Y14F), or empty vector (EV) as indicated. After 36 hours, cells were harvested and cell lysates were subjected to immunoprecipitation with antibody to CAV1 and the presence of associated GRK2 was assessed by immunoblotting with antibody to GRK2; additional controls included a sample of $10 \%$ of the cell lysate and immunoprecipitated IgG. Further controls included measurement of CAV1 protein levels after transfection by immunoblotting with antibody to CAV1. A representative image is shown. D: Conditioned medium from SECs in $\mathrm{C}$ and the cells from caveolin 1 wild-type mice $\left(\mathrm{Cav1}^{+/+}\right)$were collected, nitrite levels were measured, and the data presented graphically. Data are presented as means \pm SEM (A, B, and D). $n=3$ for each group (A, B, and D). ${ }^{*} P<0.05,{ }^{* *} P<0.01$ versus no treatment $(\mathbf{A}$ and $\mathbf{B})$ or cells from Cav1 ${ }^{+/+}$with EV (D); ${ }^{\dagger} P<0.05$, ${ }^{\dagger \dagger} P<0.01$ versus cells from Cav1 $^{-1-}$ with Cav1/WT. this interaction biochemically using immunoprecipitation. CAV1 coimmunoprecipitated with GRK2 (Figure 2, B and C) and eNOS (Figure 2C), and both partners were enriched in injured compared to normal cells. To determine whether CAV1 phosphorylation plays a role in protein-protein interaction, we investigated phosphorylation of CAV1 in complex with GRK2 and found that CAV1 phosphorylation was increased after liver injury (Figure 2B). These results suggest that CAV1, eNOS, and GRK2 may interact in a complex and raise the possibility that CAV1 phosphorylation facilitates its interaction with GRK2 in both normal and injured SECs.

\section{CSD and ET-1 Regulate CAV1 Interaction with GRK2}

The CSD (residues 82 to 101 of CAV1) has been reported to be an endogenous negative regulator of eNOS function, ${ }^{21,44}$ is required for the binding of CAV1 to eNOS, ${ }^{41}$ and is known to interact with other signaling proteins, such as $\mathrm{G}$ proteins ${ }^{12}$ and nonreceptor tyrosine kinases. ${ }^{45}$ On the other hand, ET-1 is a well-known stimulator of eNOS activity in endothelial cells. ${ }^{46}$ First, we examined CAV1 phosphorylation after ET-1 stimulation, including in the presence or absence of CSD. On the basis of our finding that CAV1 
phosphorylation level was low in normal cells but was high in injured cells (Figure 1, A and B), we tested the effects of ET-1 and CSD on CAV1 phosphorylation in injured cells. ET-1 caused a clear decrease in CAV1 phosphorylation (Figure 3A), whereas CSD caused an increase in CAV1 phosphorylation (Figure 3B). Interestingly, ET-1 blocked the CAV1 phosphorylation induced by CSD, most prominently after 60 to 120 minutes (Figure 3B). Next, we tested the effect of CSD and ET-1 on GRK2 binding to CAV1. CSD caused a clear increase in GRK2 and CAV1 interaction, and this was abrogated by ET-1 (Figure 3, C and D).

\section{CAV1 Tyrosine Phosphorylation Modulates CAV1 and GRK2 Interaction}

On the basis of our finding that in injured SECs, CAV1 phosphorylation and the CAV1-GRK2 interaction both were increased, we hypothesized that phosphorylation of CAV1 at tyrosine 14 (Tyr14) facilitates this interaction. After exposure of injured SECs to the tyrosine phosphorylation inhibitor, PP2, we found that not only was there reduced phospho- CAV1 associated with GRK2, but also that GRK2 association with CAV1 was inhibited in a dose-dependent manner (Figure 4, A and B). To examine whether phosphorylation of CAV1 at tyrosine 14 affects eNOS activity and NO production, CAV1 full-length cDNA (CAV1/wild type) and a tyrosine 14 mutant (CAV1/Y14F) were transfected into SECs from Cav1 knockout mice $\left(\mathrm{Cavl}^{-/-}\right)$. We found that after transduction of wild-type CAV1 into Cav1-deficient endothelial cells, GRK2 association with CAV1 was evident (Figure 4C) and NO production was similar to normal SECs (Figure 4D). In CAV1-deficient SECs after transduction with the tyrosine mutant (CAV1/Y14F), GRK2 association with CAV1 was reduced (Figure 4C) and NO production was unchanged (Figure 4D). These data confirm the importance of CAV1 phosphorylation in the CAV1-GRK2 interaction and eNOS/NO activity.

\section{GRK2 Activation by Iso Enhances CAV1 and GRK2 Interaction}

GRK2 is stimulated by activated G-protein-coupled receptors and activated G-protein $\beta \gamma$-subunits, ${ }^{47}$ and functions to phosphorylate and inactivate cell surface receptors in the heterotrimeric G-protein signaling cascade. GRK2 expression levels are up-regulated on liver injury in SECs, ${ }^{8}$ and GRK2 can desensitize $\mathrm{ET}_{\mathrm{B}}$ receptor signaling ${ }^{48}$ in injured SECs,${ }^{8,49}$ suggesting that GRK2 activation may play a role in CAV1 and eNOS signaling and activity. Because Iso, a $\beta$-adrenergic agonist, ${ }^{50}$ has been reported to induce GRK2 phosphorylation, ${ }^{29,30}$ we assessed GRK2 activity by immunoprecipitation of GRK2 from cell lysates and immunoblotting with anti-phosphotyrosine antibody ${ }^{30,51}$ after stimulation
A

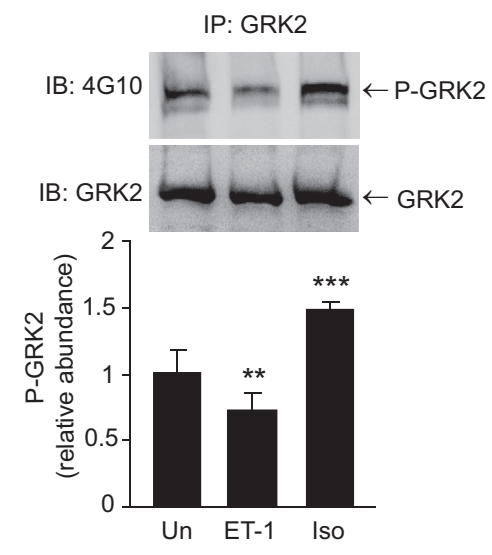

B
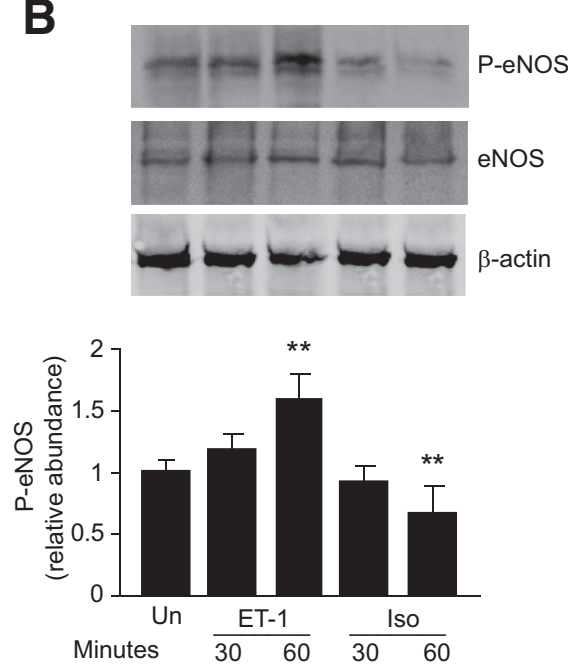

C

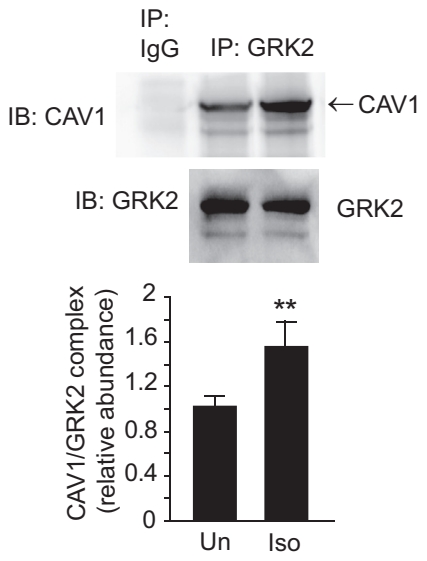

Figure 5 Dynamic agonist-mediated modulation of G-protein-coupled receptor kinase-2 (GRK2) and caveolin 1 (CAV1; GRK2-CAV1) interaction. A: Sinusoidal endothelial cells (SECS) isolated from injured [by bile duct ligation (BDL)] rat liver were grown overnight and on the next day, exposed to $10 \mu \mathrm{mol} / \mathrm{L}$ isoproterenol (Iso) or $20 \mathrm{nmol} / \mathrm{L}$ endothelin-1 (ET-1) for 1 hour. GRK2 tyrosine phosphorylation was measured by immunoprecipitation (IP) of GRK2 from cell lysates and immunoblotting (IB) with anti-phospho-tyrosine antibody (4G10); after stripping, GRK2 was analyzed in the same blot using a specific GRK2 antibody. Specific phospho-GRK2 bands were quantified and normalized to the level of total GRK2, and are presented in the graph. B: SECs from the same treatment but harvested in the time as indicated were subjected to immunoblotting with anti-phospho-endothelial nitric oxide synthase (anti-phosphoeNOS), anti-eNOS, and anti- $\beta$-actin antibodies separately. Specific bands corresponding to phospho-eNOS (P-eNOS) and total eNOS were quantified, normalized, and are presented graphically. C: SECs isolated from injured (BDL) rat livers were treated with $10 \mu \mathrm{mol} / \mathrm{L}$ Iso for 1 hour, cell lysates were immunoprecipitated with anti-GRK2 antibody, then immunoblotted to detect CAV1; GRK2 protein levels used for immunoprecipitation were assessed by immunoblotting with antibody to GRK2. Specific bands were quantified and normalized to the level of immunoprecipitated GRK2 and are presented in the graph. Immunoprecipitation with IgG is also shown as indicated. Data are presented as means \pm SEM. $n=3$ for each group $(\mathbf{A}-\mathbf{C})$. ${ }^{* *} P<0.01,{ }^{* * *} P<0.001$ versus no treatment. Un, untreated. 
with either ET-1 or Iso. ET-1 exposure decreased, but Iso exposure (to activate $\beta 2$-adrenergic receptors) increased GRK2 phosphorylation (Figure 5A), whereas ET-1 increased but Iso decreased eNOS phosphorylation (most prominently at 60 minutes) (Figure 5B). Iso exposure also led to enhanced GRK2 interaction with CAV1 (Figure 5C).

\section{Overexpression of $\mathrm{ET}_{\mathrm{B}}$ Receptor Overcomes the Effects of GRK2 and CAV1 Phosphorylation in Injured SECS}

As shown above, GRK2 and CAV1 phosphorylation led to reduced eNOS phosphorylation and activity; furthermore, this effect appeared to be facilitated by the interaction of
GRK2 with CAV1. It is known that increased GRK2 levels and activity may initiate the desensitization of endothelial receptors ${ }^{48}$ and trigger GRK2-mediated phosphorylation of proteins with a variety of cellular functions. ${ }^{52}$ To further explore the relationship between endothelin receptor signaling and GRK2-CAV1 signaling to eNOS, we first examined the $\mathrm{ET}_{\mathrm{B}}$ receptor in injured SECs. $\mathrm{ET}_{\mathrm{B}}$ receptor expression was significantly reduced after injury (Figure 6A). Despite this decrease, $\mathrm{ET}_{\mathrm{B}}$ receptor association with $\mathrm{CAV} 1^{53}$ was increased (Figure 6A). These data raise the possibility that after liver injury, $\mathrm{CAV} 1$ binding to $\mathrm{ET}_{\mathrm{B}}$ receptors reduces the potential for $\mathrm{ET}_{\mathrm{B}}$ receptors to respond to ET-1 signaling to eNOS activation. To determine whether this effect was
A

B

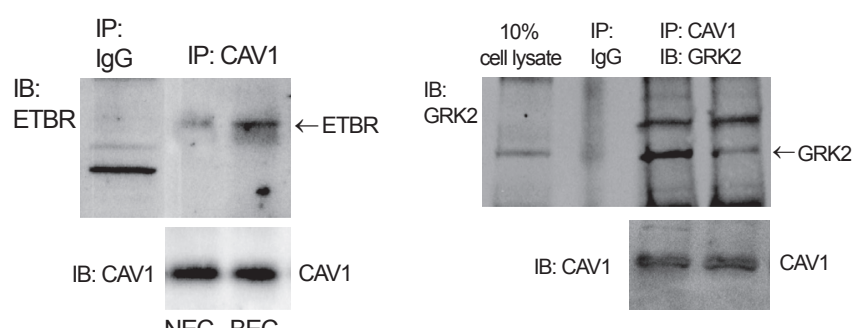

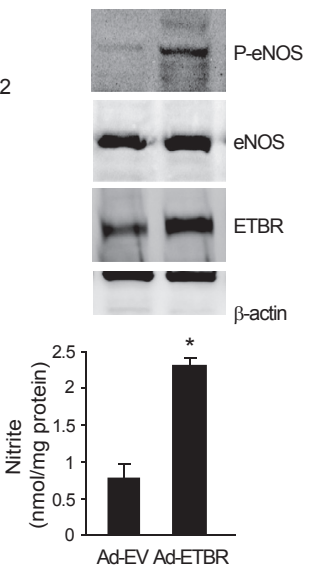

NEC BEC
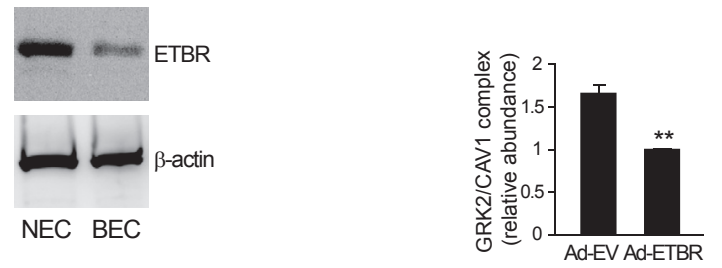

C
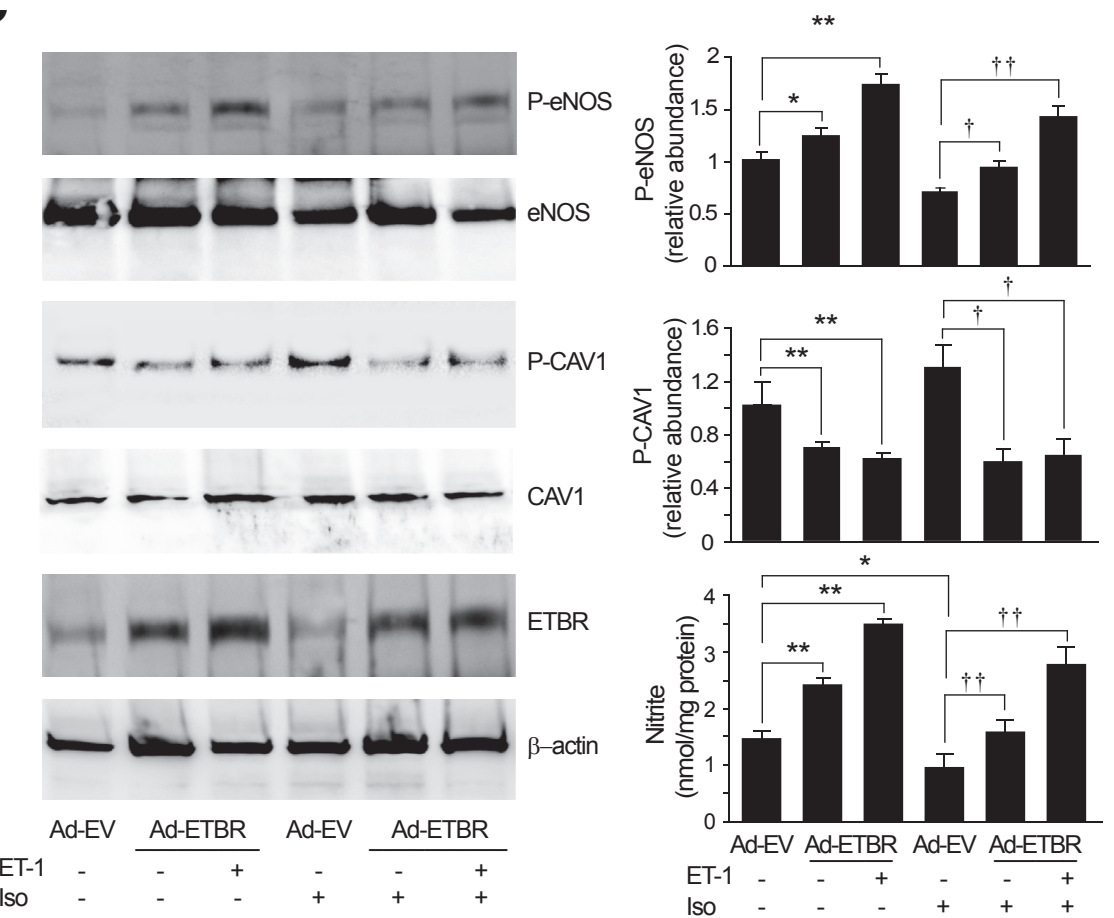

Figure $6 \quad \mathrm{ET}_{\mathrm{B}}$ receptor overexpression reduces G-protein-coupled receptor kinase-2 (GRK2) and caveolin 1 (CAV1) interaction and rescues nitric oxide (NO) production in injured sinusoidal endothelial cells (SECS). A: SECs isolated from normal or injured rat livers were subjected to immunoprecipitation (IP) with anti-CAV1 antibody, and then samples were immunoblotted (IB) with anti- $\mathrm{ET}_{B}$ receptor (ETBR) antibody, CAV1 protein levels used for immunoprecipitation were assessed by immunoblotting with anti-caveolin-1 antibody; $\mathrm{ET}_{\mathrm{B}}$ receptor and $\beta$-actin were detected in cell lysates by immunoblotting. A representative image is shown. B: SECs isolated from bile duct ligated (BDL) rat livers were transduced with recombinant adenovirus encoding the $\mathrm{ET}_{\mathrm{B}}$ receptor ( $\left.\mathrm{Ad}-\mathrm{ET}_{\mathrm{B}} \mathrm{R}\right)$ or a control empty adenovirus (Ad-EV). After 36 hours, CAV1 was immunoprecipitated with anti-CAV1 antibody, then immunoblotted to detect GRK2. Immunoprecipitation with IgG as a control and the expression of GRK2 from $10 \%$ of the total cell lysate used for immunoprecipitation are also shown; CAV1 protein levels used for immunoprecipitation were assessed by immunoblotting with anti-caveolin-1 antibody. Specific GRK2 bands were quantified and normalized to the level of immunoprecipitated CAV1 and are presented graphically; phospho-endothelial nitric oxide synthase (P-eNOS), $\mathrm{ET}_{\mathrm{B}}$ receptor, total eNOS, and CAV1 expression were measured in cell lysates by immunoblotting; conditioned media from injured SECs were harvested and nitrite production was measured, and the data are presented graphically. C: SECs isolated from BDL rat livers transduced with Ad$\mathrm{ET}_{\mathrm{B}} \mathrm{R}$ or $\mathrm{Ad}-\mathrm{EV}$, as in $\mathbf{B}$, were exposed to $20 \mathrm{nmol} / \mathrm{L}$ endothelin-1 (ET-1) and/or $10 \mu \mathrm{mol} / \mathrm{L}$ isoproterenol for additional 1 hour, as indicated. SECs were harvested, and P-eNOS, P-CAV1, ET $\mathrm{B}$ receptor, total eNOS, total CAV1, and $\beta$-actin were detected by immunoblotting, as indicated. Bands corresponding to P-eNOS or P-CAV1 were quantified and normalized to the level of total eNOS or total CAV1, respectively, and presented graphically; conditioned medium was collected, and nitrite levels were measured, and the data are presented graphically. Data are presented as means \pm SEM. $n=3$ for each group (B and $\mathbf{C}$ ). ${ }^{*} P<0.05,{ }^{*} * P<0.01$ versus $\mathrm{Ad}-\mathrm{EV} ;{ }^{\dagger} P<0.05$, ${ }^{\dagger \dagger} P<0.005$ versus Ad-EV with isoproterenol. BEC, injured sinusoidal endothelial cells by BDL; NEC, normal sinusoidal endothelial cells with shamoperation. 
reversible, we overexpressed $\mathrm{ET}_{\mathrm{B}}$ receptors in injured SECs, and found this to dramatically increase $\mathrm{NO}$ production (Figure 6B) and eNOS phosphorylation (Figure 6C). Furthermore, receptor expression partially restored the eNOS phosphorylation that had been inhibited by Iso, whereas it also suppressed CAV1 phosphorylation (Figure $6 \mathrm{C}$ ). ET $_{\mathrm{B}}$ receptor expression also inhibited the CAV1-GRK2 interaction (Figure $6 \mathrm{~B}$ ), indicating that desensitization of the $\mathrm{ET}_{\mathrm{B}}$ receptor caused by GRK2 activation ${ }^{48}$ in injured cells can be rescued by restoring $\mathrm{ET}_{\mathrm{B}}$ receptors.

\section{Discussion}

Herein, we have shown that CAV1-GRK2 interaction is enhanced by CAV1 phosphorylation on tyrosine-14 after liver injury. We have also shown that the interaction between CAV1 and GRK2 requires CAV1 tyrosine-14 phosphorylation (Figure 4) and GRK2 phosphorylation (Figures 5 and 6). The functional consequence of this CAV1-GRK2 interaction is a reduction in eNOS phosphorylation and eNOS activity (Figure 1).

The current study extends previous data demonstrating that CAV1 and GRK2 each negatively regulate eNOS activity after their interaction with eNOS. In previous work, it was shown that eNOS and CAV1 interact directly and the interaction affects eNOS activity. ${ }^{40}$ In the heart, it was shown that eNOS and GRK2 interact to form a key nodal point that determines outcomes of ischemic injury, because increased GRK2 activity or decreased eNOS activity lead to $\beta$-adrenergic receptor desensitization and myocyte injury. ${ }^{7}$ Herein, we demonstrate CAV1 and GRK2 together regulate eNOS. In addition, CAV1 tyrosine-14 phosphorylation (Figure 4, A and B) is required, as evidenced by the effect of inhibition of CAV1 phosphorylation by PP2. Previous data indicating that CAV1 can be tyrosine phosphorylated by the Src kinase family, ${ }^{54}$ and that Src activation and CAV1 phosphorylation leads to increased eNOS/CAV1 interaction $^{28}$ support our findings. In addition, our finding that injured SECs possess an elevated level of P-CAV1 within the CAV1-GRK2 complex (Figure 2B), leading to the inhibition of eNOS activation, further suggests that CAV1 phosphorylation is critical in CAV1-GRK2-mediated suppression of eNOS activation in injured cells.

Previous data have shown that GRK2 possesses caveolinbinding motifs, located in $\mathrm{PH}$ (residues 567 to 584) and RH (residues 63 to 71 ) domains. ${ }^{43}$ These data also

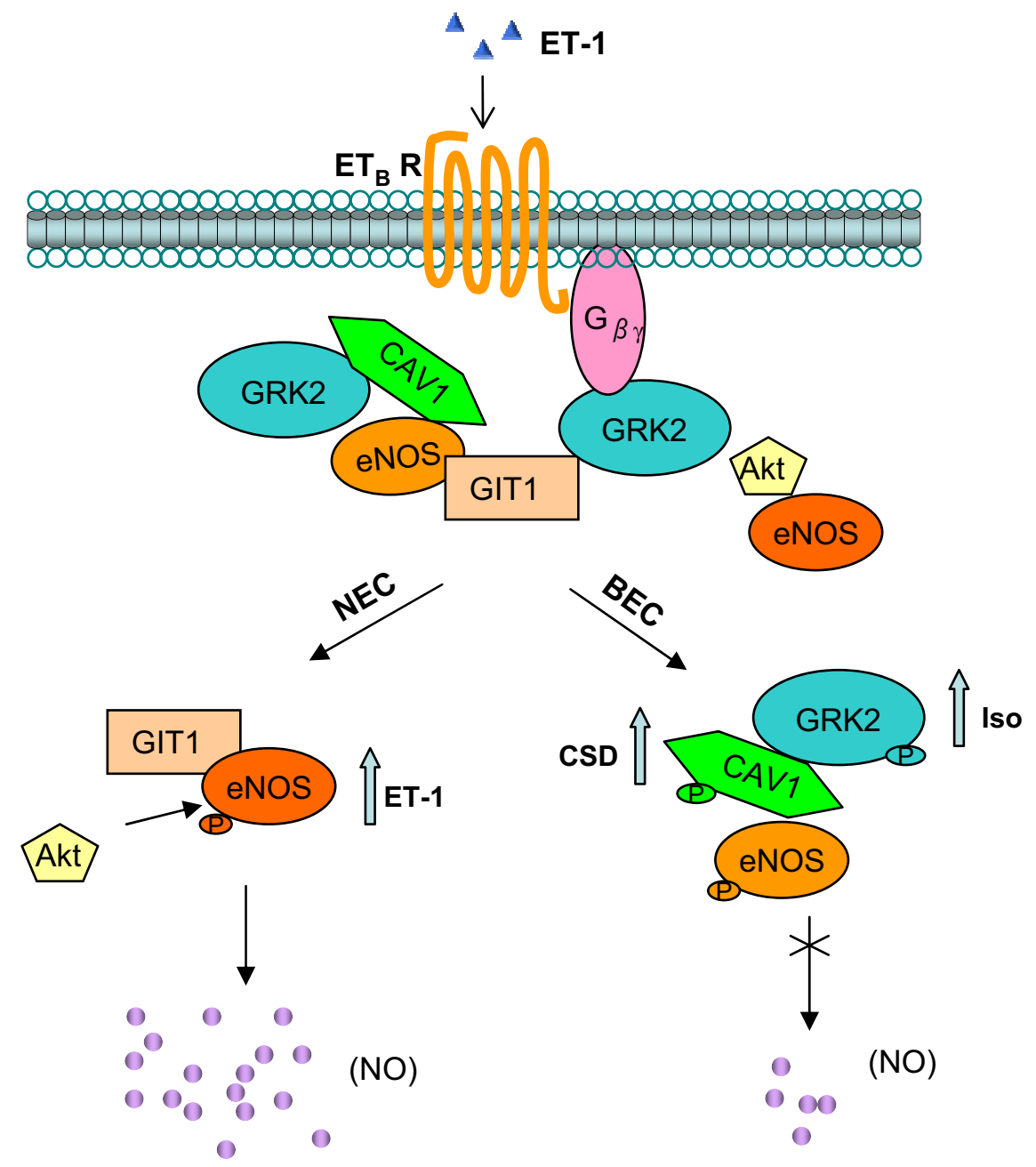

Figure 7 A proposed model for G-proteincoupled receptor kinase-2 (GRK2)/caveolin 1 (CAV1) signaling in normal and injured sinusoidal endothelial cells (SECS). In SECS, G-protein -coupled endothelin $B$ receptors $\left(\mathrm{ET}_{\mathrm{B}}\right.$ receptor) activate $\mathrm{G} \beta \gamma / \mathrm{GRK} 2$ and link CAV1/GRK2 complexes with GIT1/endothelial nitric oxide synthase (eNOS). There are several differences between the normal and injured state. In normal SECs, GIT1 interacts with eNOS to promote eNOS phosphorylation, and Akt increases this interaction and enhances eNOS activity. ${ }^{32,36}$ In injured SECs, CAV1 phosphorylation and GRK2 expression and activity are increased, enhancing the GRK2-CAV1 interaction and resulting in eNOS being more tightly held in its inactive state. CAV1 phosphorylation by CAV1 scaffolding domain or/and GRK2 activity increase by isoproterenol (Iso) will enhance CAV1-GRK2 association, further inactivating eNOS. These interlinked pathways lead to reduction of nitric oxide (NO) production. BEC, injured sinusoidal endothelial cells by BDL; ET-1, endothelin-1; NEC, normal sinusoidal endothelial cells. 
support the concept that caveolae appear to be a key locus in G-protein-coupled receptor signal transduction. ${ }^{55}$ A previous study indicating that CAV1, through its scaffolding domain, regulates GRK2 function is consistent with this concept. ${ }^{6}$ Herein, we show that the CSD induces CAV1 phosphorylation at Tyr-14, and this is attenuated by ET-1 (Figure 3B). Furthermore, ET-1 alters the GRK2-CAV1 interaction (Figure 3, C and D). Note that CSD peptide is reported to alter CAV1 phosphorylation, ${ }^{56}$ block eNOS activity and cellular NO release, ${ }^{21}$ mediate the membrane binding of CAV1, ${ }^{57}$ and play essential roles in caveolin protein-protein interactions, ${ }^{58}$ such as with Rho GTPases. ${ }^{59}$ Recently, a construct with a mutation in the CAV1 scaffolding domain was found to disrupt the actions of endogenous CAV1 toward eNOS in endothelial cells and enhance NO release. ${ }^{44}$ In this setting, it is possible that CSD also has a critical role in mediating the GRK2-CAV1 interaction in injured SECs.

In this study, we have extended the GRK2 signaling paradigm to include CAV1, eNOS, and NO. We believe that in injured SECs, GRK2 binding to CAV1 leads to eNOS becoming bound in the same complex, resulting in a blockade of eNOS activity (Figure 2C). The $\beta$-adrenergic receptor agonist Iso increased GRK2 tyrosine phosphorylation (Figure 5A) and GRK2-CAV1 interaction (Figure 5C), and further inhibited eNOS activity (Figure 5B). Liver injury leads to increased GRK2 expression and reduced eNOS activity in SECs, ${ }^{8}$ and failing myocardium leads to increased GRK2, resulting in enhanced desensitization of $\beta$-adrenergic receptor and other GPCRs on the sarcolemmal membrane of cardiomyocytes. ${ }^{60}$ Now, we have shown that CAV1 binding appears to be important in the GRK2/eNOS scaffold, promoting the negative signaling effect of GRK2 on eNOS. However, several questions remain, in particular: how does CAV1 phosphorylation mechanistically stimulate GRK2 to regulate eNOS function?

We also found that overexpression of the $\mathrm{ET}_{\mathrm{B}}$ receptor increased eNOS phosphorylation and NO production, and partially rescued the inhibition of eNOS activity by Iso (through stimulating GRK2 tyrosine phosphorylation) (Figure 6, B and C). These results suggest that in injured SECs, the decline in ET-1/ET $\mathrm{B}_{\mathrm{B}}$ receptor-mediated eNOS activity may be caused by either (or both) a reduction in $\mathrm{ET}_{\mathrm{B}}$ receptor expression or an increase in interaction of the $\mathrm{ET}_{\mathrm{B}}$ receptor with CAV1. This may lead to a decrease in the amount of $\mathrm{ET}_{\mathrm{B}}$ receptor available to be stimulated by ET-1. In addition, $\beta$-adrenergic agonists (eg, Iso) are expected to increase the activity of GRK2, ${ }^{30,51}$ further triggering the interaction with CAV1 through modulating $\mathrm{ET}_{\mathrm{B}}$ receptor desensitization. ${ }^{48,61} \mathrm{We}$ propose that increased GRK2 expression (and activity) in injured SECs results in increased desensitization of endothelial G-protein receptors and also alters GPCR-independent signaling mediated through direct interaction with GRK2, such as occurs with caveolin and eNOS, all resulting in attenuation of ET-1 signaling toward eNOS in injured SECs (Figure 7).
In summary, we have shown that both eNOS and GRK2 interact with CAV1. In addition, this interaction involves the CSD and appears to require CAV1 tyrosine phosphorylation, which, in turn, modulates GRK2 phosphorylation, together leading to reduced eNOS function. Most important, this system is dysregulated in injured SECs. Taken together, the data suggest that CAV1 and GRK2 work together as critical modulators of eNOS function.

\section{Acknowledgments}

We thank Michael B. Fallon (The University of Texas Health Science Center at Houston, Houston, TX) for the adenovirus containing full-length endothelin-B receptor.

S.L., R.T.P., and D.C.R. designed the study; S.L. and S.S. acquired data; S.L., R.T.P., S.S., and D.C.R. analyzed and interpreted data; S.L. and D.C.R. wrote the manuscript; S.L., R.T.P., and D.C.R. revised the manuscript; D.C.R. provided administrative support.

\section{References}

1. Forstermann U, Closs EI, Pollock JS, Nakane M, Schwarz P, Gath I, Kleinert H: Nitric oxide synthase isozymes: characterization, purification, molecular cloning, and functions. Hypertension 1994, 23: $1121-1131$

2. Jones SP, Girod WG, Palazzo AJ, Granger DN, Grisham MB, Jourd'Heuil D, Huang PL, Lefer DJ: Myocardial ischemiareperfusion injury is exacerbated in absence of endothelial cell nitric oxide synthase. Am J Physiol 1999, 276:H1567-H1573

3. Heeringa P, van Goor H, Itoh-Lindstrom Y, Maeda N, Falk RJ, Assmann KJ, Kallenberg CG, Jennette JC: Lack of endothelial nitric oxide synthase aggravates murine accelerated anti-glomerular basement membrane glomerulonephritis. Am J Pathol 2000, 156: 879-888

4. Rockey DC, Chung JJ: Reduced nitric oxide production by endothelial cells in cirrhotic rat liver: endothelial dysfunction in portal hypertension. Gastroenterology 1998, 114:344-351

5. Shah V, Toruner M, Haddad F, Cadelina G, Papapetropoulos A, Choo K, Sessa WC, Groszmann RJ: Impaired endothelial nitric oxide synthase activity associated with enhanced caveolin binding in experimental cirrhosis in the rat. Gastroenterology 1999, 117: $1222-1228$

6. Carman CV, Lisanti MP, Benovic JL: Regulation of G proteincoupled receptor kinases by caveolin. J Biol Chem 1999, 274: $8858-8864$

7. Huang ZM, Gao E, Fonseca FV, Hayashi H, Shang X, Hoffman NE, Chuprun JK, Tian X, Tilley DG, Madesh M, Lefer DJ, Stamler JS, Koch WJ: Convergence of $\mathrm{G}$ protein-coupled receptor and S-nitrosylation signaling determines the outcome to cardiac ischemic injury. Sci Signal 2013, 6:ra95

8. Liu S, Premont RT, Kontos CD, Zhu S, Rockey DC: A crucial role for GRK2 in regulation of endothelial cell nitric oxide synthase function in portal hypertension. Nat Med 2005, 11: 952-958

9. Penela P, Murga C, Ribas C, Lafarga V, Mayor F Jr: The complex G protein-coupled receptor kinase 2 (GRK2) interactome unveils new physiopathological targets. Br J Pharmacol 2010, 160:821-832

10. Bastiani M, Parton RG: Caveolae at a glance. J Cell Sci 2010, 123 : 3831-3836

11. Razani B, Woodman SE, Lisanti MP: Caveolae: from cell biology to animal physiology. Pharmacol Rev 2002, 54:431-467 
12. Li S, Okamoto T, Chun M, Sargiacomo M, Casanova JE, Hansen SH, Nishimoto I, Lisanti MP: Evidence for a regulated interaction between heterotrimeric G proteins and caveolin. J Biol Chem 1995, 270: 15693-15701

13. Li S, Couet J, Lisanti MP: Src tyrosine kinases, Galpha subunits, and H-Ras share a common membrane-anchored scaffolding protein, caveolin: caveolin binding negatively regulates the auto-activation of Src tyrosine kinases. J Biol Chem 1996, 271:29182-29190

14. Garcia-Cardena G, Fan R, Stern DF, Liu J, Sessa WC: Endothelial nitric oxide synthase is regulated by tyrosine phosphorylation and interacts with caveolin-1. J Biol Chem 1996, 271:27237-27240

15. Yamaguchi T, Murata Y, Fujiyoshi Y, Doi T: Regulated interaction of endothelin B receptor with caveolin-1. Eur J Biochem 2003, 270: $1816-1827$

16. Razani B, Wang XB, Engelman JA, Battista M, Lagaud G, Zhang XL, Kneitz B, Hou H Jr, Christ GJ, Edelmann W, Lisanti MP: Caveolin-2-deficient mice show evidence of severe pulmonary dysfunction without disruption of caveolae. Mol Cell Biol 2002, 22: 2329-2344

17. Rothberg KG, Heuser JE, Donzell WC, Ying YS, Glenney JR, Anderson RG: Caveolin, a protein component of caveolae membrane coats. Cell 1992, 68:673-682

18. Wang XM, Zhang Y, Kim HP, Zhou Z, Feghali-Bostwick CA, Liu F, Ifedigbo E, Xu X, Oury TD, Kaminski N, Choi AM: Caveolin-1: a critical regulator of lung fibrosis in idiopathic pulmonary fibrosis. J Exp Med 2006, 203:2895-2906

19. Couet J, Shengwen L, Okamoto T, Scherer PE, Lisanti MP: Molecular and cellular biology of caveolae paradoxes and plasticities. Trends Cardiovasc Med 1997, 7:103-110

20. Zhao YY, Liu Y, Stan RV, Fan L, Gu Y, Dalton N, Chu PH, Peterson K, Ross J Jr, Chien KR: Defects in caveolin-1 cause dilated cardiomyopathy and pulmonary hypertension in knockout mice. Proc Natl Acad Sci U S A 2002, 99:11375-11380

21. Bucci M, Gratton JP, Rudic RD, Acevedo L, Roviezzo F, Cirino G, Sessa WC: In vivo delivery of the caveolin-1 scaffolding domain inhibits nitric oxide synthesis and reduces inflammation. Nat Med 2000, 6:1362-1367

22. Feron O, Belhassen L, Kobzik L, Smith TW, Kelly RA, Michel T: Endothelial nitric oxide synthase targeting to caveolae: specific interactions with caveolin isoforms in cardiac myocytes and endothelial cells. J Biol Chem 1996, 271:22810-22814

23. Michel JB, Feron O, Sacks D, Michel T: Reciprocal regulation of endothelial nitric-oxide synthase by $\mathrm{Ca} 2+$-calmodulin and caveolin. J Biol Chem 1997, 272:15583-15586

24. Drab M, Verkade P, Elger M, Kasper M, Lohn M, Lauterbach B, Menne J, Lindschau C, Mende F, Luft FC, Schedl A, Haller H, Kurzchalia TV: Loss of caveolae, vascular dysfunction, and pulmonary defects in caveolin-1 gene-disrupted mice. Science 2001, 293: 2449-2452

25. Razani B, Combs TP, Wang XB, Frank PG, Park DS, Russell RG, Li M, Tang B, Jelicks LA, Scherer PE, Lisanti MP: Caveolin-1deficient mice are lean, resistant to diet-induced obesity, and show hypertriglyceridemia with adipocyte abnormalities. J Biol Chem 2002, 277:8635-8647

26. Grande-Garcia A, Echarri A, de Rooij J, Alderson NB, WatermanStorer CM, Valdivielso JM, del Pozo MA: Caveolin-1 regulates cell polarization and directional migration through Src kinase and Rho GTPases. J Cell Biol 2007, 177:683-694

27. Gottlieb-Abraham E, Shvartsman DE, Donaldson JC, Ehrlich M, Gutman O, Martin GS, Henis YI: Src-mediated caveolin-1 phosphorylation affects the targeting of active Src to specific membrane sites. Mol Biol Cell 2013, 24:3881-3895

28. Chen Z, Bakhshi FR, Shajahan AN, Sharma T, Mao M, Trane A, Bernatchez P, van Nieuw Amerongen GP, Bonini MG, Skidgel RA, Malik AB, Minshall RD: Nitric oxide-dependent Src activation and resultant caveolin-1 phosphorylation promote eNOS/caveolin-1 binding and eNOS inhibition. Mol Biol Cell 2012, 23:1388-1398
29. Lorenz K, Lohse MJ, Quitterer U: Protein kinase C switches the Raf kinase inhibitor from Raf-1 to GRK-2. Nature 2003, 426:574-579

30. Sarnago S, Elorza A, Mayor F Jr: Agonist-dependent phosphorylation of the G protein-coupled receptor kinase 2 (GRK2) by Src tyrosine kinase. J Biol Chem 1999, 274:34411-34416

31. Kountouras J, Billing BH, Scheuer PJ: Prolonged bile duct obstruction: a new experimental model for cirrhosis in the rat. Br J Exp Pathol 1984, 65:305-311

32. Liu S, Premont RT, Rockey DC: G-protein-coupled receptor kinase interactor-1 (GIT1) is a new endothelial nitric-oxide synthase (eNOS) interactor with functional effects on vascular homeostasis. J Biol Chem 2012, 287:12309-12320

33. Razani B, Lisanti MP: Caveolin-deficient mice: insights into caveolar function human disease. J Clin Invest 2001, 108:1553-1561

34. Rockey DC, Chung JJ: Interferon gamma inhibits lipocyte activation and extracellular matrix mRNA expression during experimental liver injury: implications for treatment of hepatic fibrosis. J Investig Med 1994, 42:660-670

35. Singh S, Liu S, Rockey DC: Caveolin-1 is upregulated in hepatic stellate cells but not sinusoidal endothelial cells after liver injury. Tissue Cell 2016, 48:126-132

36. Liu S, Premont RT, Kontos CD, Huang J, Rockey DC: Endothelin-1 activates endothelial cell nitric-oxide synthase via heterotrimeric Gprotein betagamma subunit signaling to protein jinase B/Akt. J Biol Chem 2003, 278:49929-49935

37. Tang L, Luo B, Patel RP, Ling Y, Zhang J, Fallon MB: Modulation of pulmonary endothelial endothelin $\mathrm{B}$ receptor expression and signaling: implications for experimental hepatopulmonary syndrome. Am J Physiol Lung Cell Mol Physiol 2007, 292:L1467-L1472

38. Yu Q, Que LG, Rockey DC: Adenovirus-mediated gene transfer to nonparenchymal cells in normal and injured liver. Am J Physiol Gastrointest Liver Physiol 2002, 282:G565-G572

39. Lajoie P, Partridge EA, Guay G, Goetz JG, Pawling J, Lagana A, Joshi B, Dennis JW, Nabi IR: Plasma membrane domain organization regulates EGFR signaling in tumor cells. J Cell Biol 2007, 179: 341-356

40. Ju H, Zou R, Venema VJ, Venema RC: Direct interaction of endothelial nitric-oxide synthase and caveolin-1 inhibits synthase activity. J Biol Chem 1997, 272:18522-18525

41. Garcia-Cardena G, Martasek P, Masters BS, Skidd PM, Couet J, Li S, Lisanti MP, Sessa WC: Dissecting the interaction between nitric oxide synthase (NOS) and caveolin: functional significance of the nos caveolin binding domain in vivo. J Biol Chem 1997, 272: $25437-25440$

42. Huang ZM, Gao E, Chuprun JK, Koch WJ: GRK2 in the heart: a GPCR kinase and beyond. Antioxid Redox Signal 2014, 21: 2032-2043

43. Ribas C, Penela P, Murga C, Salcedo A, Garcia-Hoz C, JuradoPueyo M, Aymerich I, Mayor F Jr: The G protein-coupled receptor kinase (GRK) interactome: role of GRKs in GPCR regulation and signaling. Biochim Biophys Acta 2007, 1768:913-922

44. Bernatchez P, Sharma A, Bauer PM, Marin E, Sessa WC: A noninhibitory mutant of the caveolin-1 scaffolding domain enhances eNOS-derived NO synthesis and vasodilation in mice. J Clin Invest 2011, 121:3747-3755

45. Couet J, Sargiacomo M, Lisanti MP: Interaction of a receptor tyrosine kinase, EGF-R, with caveolins: caveolin binding negatively regulates tyrosine and serine/threonine kinase activities. J Biol Chem 1997, 272:30429-30438

46. Yanagisawa M, Kurihara H, Kimura S, Tomobe Y, Kobayashi M, Mitsui Y, Yazaki Y, Goto K, Masaki T: A novel potent vasoconstrictor peptide produced by vascular endothelial cells. Nature 1988 , 332:411-415

47. Daaka Y, Pitcher JA, Richardson M, Stoffel RH, Robishaw JD, Lefkowitz RJ: Receptor and G betagamma isoform-specific interactions with G protein-coupled receptor kinases. Proc Natl Acad Sci U S A 1997, 94:2180-2185 
48. Freedman NJ, Ament AS, Oppermann M, Stoffel RH, Exum ST, Lefkowitz RJ: Phosphorylation and desensitization of human endothelin A and B receptors: evidence for $\mathrm{G}$ protein-coupled receptor kinase specificity. J Biol Chem 1997, 272:17734-17743

49. Evron T, Daigle TL, Caron MG: GRK2: multiple roles beyond G protein-coupled receptor desensitization. Trends Pharmacol Sci 2012, 33:154-164

50. Hausdorff WP, Bouvier M, O’Dowd BF, Irons GP, Caron MG, Lefkowitz RJ: Phosphorylation sites on two domains of the beta 2adrenergic receptor are involved in distinct pathways of receptor desensitization. J Biol Chem 1989, 264:12657-12665

51. Murthy KS, Mahavadi S, Huang J, Zhou H, Sriwai W: Phosphorylation of GRK2 by PKA augments GRK2-mediated phosphorylation, internalization, and desensitization of VPAC2 receptors in smooth muscle. Am J Physiol Cell Physiol 2008, 294: C477-C487

52. Penela P, Murga C, Ribas C, Tutor AS, Peregrin S, Mayor F Jr: Mechanisms of regulation of $\mathrm{G}$ protein-coupled receptor kinases (GRKs) and cardiovascular disease. Cardiovasc Res 2006, 69:46-56

53. Chun M, Liyanage UK, Lisanti MP, Lodish HF: Signal transduction of a $\mathrm{G}$ protein-coupled receptor in caveolae: colocalization of endothelin and its receptor with caveolin. Proc Natl Acad Sci U S A 1994, 91:11728-11732

54. Glenney JR Jr, Soppet D: Sequence and expression of caveolin, a protein component of caveolae plasma membrane domains phosphorylated on tyrosine in Rous sarcoma virus-transformed fibroblasts. Proc Natl Acad Sci U S A 1992, 89:10517-10521
55. Ostrom RS, Insel PA: The evolving role of lipid rafts and caveolae in G protein-coupled receptor signaling: implications for molecular pharmacology. Br J Pharmacol 2004, 143:235-245

56. Rathor N, Zhuang R, Wang JY, Donahue JM, Turner DJ, Rao JN: Src-mediated caveolin-1 phosphorylation regulates intestinal epithelial restitution by altering $\mathrm{Ca}(2+)$ influx after wounding. Am J Physiol Gastrointest Liver Physiol 2014, 306:G650-G658

57. Schlegel A, Schwab RB, Scherer PE, Lisanti MP: A role for the caveolin scaffolding domain in mediating the membrane attachment of caveolin1: the caveolin scaffolding domain is both necessary and sufficient for membrane binding in vitro. J Biol Chem 1999, 274:22660-22667

58. Byrne DP, Dart C, Rigden DJ: Evaluating caveolin interactions: do proteins interact with the caveolin scaffolding domain through a widespread aromatic residue-rich motif? PLoS One 2012, 7:e44879

59. Arpaia E, Blaser H, Quintela-Fandino M, Duncan G, Leong HS, Ablack A, Nambiar SC, Lind EF, Silvester J, Fleming CK, Rufini A, Tusche MW, Brustle A, Ohashi PS, Lewis JD, Mak TW: The interaction between caveolin-1 and Rho-GTPases promotes metastasis by controlling the expression of alpha5-integrin and the activation of Src, Ras and Erk. Oncogene 2012, 31:884-896

60. Vinge LE, Oie E, Andersson Y, Grogaard HK, Andersen G, Attramadal H: Myocardial distribution and regulation of GRK and beta-arrestin isoforms in congestive heart failure in rats. Am J Physiol Heart Circ Physiol 2001, 281:H2490-H2499

61. Penela P, Ribas C, Mayor F Jr: Mechanisms of regulation of the expression and function of $\mathrm{G}$ protein-coupled receptor kinases. Cell Signal 2003, 15:973-981 